\title{
ENGLISH-MAJORED STUDENTS' ATTITUDES TOWARDS PRAGMATIC AWARENESS
}

\author{
Nguyễn Tất Thắng* \\ Dalat University \\ 01 Phu Dong Thien Vuong, Dalat, Vietnam \\ Received 22 April 2020 \\ Revised 22 August 2020; Accepted 22 January 2021
}

\begin{abstract}
Good command of language, e.g. vocabulary, grammar, does not always guarantee success in communication. Learners of language need to be equipped with both language and the knowledge of how to use it, i.e. pragmatics. This paper investigates the attitudes of English-majored students at a university in Vietnam towards the knowledge of pragmatics of language learners. Data was collected via a questionnaire and the software SPSS version 20 was used for the analysis. The results showed that the majority of investigated students were aware of the role of pragmatics in their language classes. First year students and fourth year students differed in 3 issues: 1) whether good knowledge of language being enough for communication; 2) willingness to take a course on pragmatics; 3 ) teachers presenting the knowledge of how to use language officially in classes of language. This indicates that instruction about pragmatic knowledge should be taken into consideration in material design and in language classes.
\end{abstract}

Keywords: pragmatics, communication, perspectives, language use

\section{Introduction}

In the era of globalization, the demand of learning a foreign language is as vibrant as it has never been. However, it could be a mistake to think that learning how to communicate is to learn word meanings, pronunciation, and sentence structures. In the mid- $20^{\text {th }}$ century, Chomsky (1965) distinguished the differences between language competence and language performance. The former concept refers to what a person knows and the latter refers to what a person does in terms of linguistic communication. The amount of knowledge about language a person owns does not guarantee that $\mathrm{s} / \mathrm{he}$ will be successful in his/ her communication. This partially depends on the knowledge of pragmatics $\mathrm{s} / \mathrm{he}$ has. Pragmatic competence plays a vital role in one's success in communication (Bachman, 1990). Therefore, the issue of how to increase learner's pragmatic knowledge has been of interest to many scholars so far.

This study is an attempt to discover English-majored students' awareness of pragmatic knowledge and their attitude toward the role of pragmatic knowledge in communication. It is also aimed at discovering whether there are differences, if any, between first- and fourth-year students in realizing the role of pragmatic knowledge in language learning and teaching.

In order to reach the aims set forth, the paper is going to seek the answers to the following two questions: 1) What are the attitudes of English-majored students towards the role of pragmatic knowledge in language learning and teaching? and 2) Are there any differences between first- and fourth-year students in their realization of the pragmatic role in language classes?

*Tel.: 0913.818.418, Email: thangnt@dlu.edu.vn 


\section{Literature review}

\subsection{Pragmatic competence in communication}

It is obvious that our communicative competence does not confine itself in vocabulary capacity or grammatical skills, but actually expands to social and cultural appropriateness in language use (Byram et al., 2002). Bardovi-Harlig and Dornyei (1997) state that in the process of language learning, grammatical development does not guarantee a corresponding level of pragmatic development. One utterance may be appropriate in this situation in this culture, but that might not be accepted in other situations or in other cultures. Linguists call this knowledge 'pragmatic competence'.

According to Taguchi (2009, p. 1), pragmatic competence is "the ability to use language appropriately in a social context". Different social contexts require different norms, i.e. specific utterances properly used in each situation. Bachman (1990) considers pragmatic competence to be independent from grammatical and discourse organization, and pragmatic competence is associated with the functional aspect of language which leads to success in communication. Grossi (2009) reports that pragmatic competence plays a significant role in second language acquisition, and accordingly in overall communicative competence.

As a result, in the context of language teaching and learning, the issue of pragmatics cannot be ignored. Barron (2003, p. 10) states that pragmatic competence in a second/ foreign language environment is the ability to use the target in a contextually appropriate fashion to understand the language in context and to attain communicative goals.

\subsection{Pragmatic awareness and its role in language teaching and learning}

According to Schmidt (2010, p. 27), pragmatic awareness is necessary for the acquisition of pragmatic knowledge because "people learn about the things that they pay attention to and do not learn much about the things they do not attend to". Pragmatic awareness is defined as L2 learners' "conscious and explicit knowledge about the appropriateness of language use constrained by communication contexts" (Li, Suleiman, \& Sazalie, 2015). Obviously, it is not automatic that students studying a language would be able to learn the appropriateness of sentences/ utterances without consciously working on it.

It is clear that learning a language does not confine itself in learning vocabulary, pronunciation, grammar, or meanings, but it includes the issue of learning how to use that vocabulary or grammar properly in different contexts. Inappropriate use of language may lead to disaster in communication. BardoviHarlig et al. (1991, p. 13) state that "teaching pragmatics empowers students to experience and experiment with the language at a deeper level, and thereby to participate in the purpose of language - communication, rather than just words".

One different idea comes from EslamiRasekh (2005) who states that one important issue is "whether learners need to be taught pragmatics", and that "it can be argued that perhaps pragmatic knowledge simply develops alongside lexical and grammatical knowledge, without requiring any pedagogic intervention". However, Kasper (1997) states that the results from studies of the pragmatic competence of adult foreign and second language learners have indicated that the knowledge of pragmatics of learners and native speakers are quite different. Language learners need instruction for the understanding of how to use language appropriately.

In support to the role of pragmatic teaching, Vásquez and Sharpless (2009) reveal the 
importance of teaching pragmatics to language learners. They indicate that pragmatic issues are more important and time consuming than grammatical ones; therefore, they require much longer time and efforts. In other words, to reach a certain level of pragmatic awareness in language usage, language learners need a certain amount of time and appropriate input in their language classrooms.

Regarding the level of awareness, Schmidt (1995) suggests that there are two elements, namely noticing and understanding. Noticing is the "conscious registration of the occurrence of some event", referring to the surface of the issue in language usage. Understanding is the "recognition of a general principle, rule or pattern", referring to the abstract level of learners in language usage. Therefore, it is obvious that language learners should be provided with opportunities to notice the patterns in language usage as well as to understand how language works.

As a result, the vital role of teaching/ learning pragmatics should be taken into account. Teachers and students of language should be equipped with the realization of the importance of studying pragmatics. This is, therefore, the motivation for this research to be carried out.

\subsection{Previous studies about pragmatic knowledge in language learners}

Le (2006) studies the effects of teaching communication strategies to Vietnamese students with the participants from Hue University. She finds that the group of students who are introduced to communication strategies are more willing to communicate with English-speaking tourists than the group who have not been previously introduced to communication strategies. She suggests that teaching communication strategies might boost learners' fluency in language use.
Nguyen, Pham, and Pham (2012) carry out a study to measure the impact of explicit and implicit form-focused instruction about the development of the speech act of constructive criticism. The study finds that the group with explicit metapragmatic explanation, and correction of pragmatic and grammatical errors outperform the group with implicit strategy.

Ifantidou (2013) carries out a study to discover the effects of explicit instruction on learners' different aspects of pragmatic competence. The study found that it is effective to use explicit instruction on developing learners' pragmatic competence.

Rezvani, Eslami-Rasekh, and Dastjerdi's study (2014) indicates that both explicit and implicit intervention could produce a significant improvement to the learners' production of requests and suggestions. This means that explicit or implicit instruction could bring about similar pragmatic achievement.

Li et al. (2015) find out that teachers concern more about the language accuracy and fluency of their students, and do not realize the role of pragmatic knowledge in communication. When they do, they are not clear about what their students have already learned and what students still need to know about pragmatics of the target language.

As there is not a clear-cut solution to the strategy of introducing pragmatic knowledge to students, this study focuses on the students' perception of the role of pragmatics in their language studies. This could hopefully add to the literature of the teaching and learning pragmatics in this English language dominating world.

\section{Methodology}

\subsection{Research design}

Quantitative approach was mainly applied in this research. Quantitative method was used to collect the data and produce the output 
based on SPSS software. In order to maximize the significance of the research and to clarify the data collected, qualitative method was also used in analyzing and explaining the results.

\subsection{Participants}

The participants of the study included English-majored students at a university in Vietnam, who were learning English as a major for their future career. The participants came from two groups. The first one consisted of 102 students who just started their English major at the university. The second group consisted of 81 fourth year students who had been taking the course of Introduction to Pragmatics. They were, to a certain extent, able to understand the notions of pragmatics in language learning.

\subsection{Instruments}

Each group received a questionnaire consisting of questions related to pragmatic knowledge. The questionnaire for the firstyear students consisted of 17 questions (see Appendix 1 for more information). The questionnaire was adapted from the instrument used by Schauer (2006) and Ekin and Damar (2013). The questions were classified into several criteria. The first was to ask their perspective on whether there should be a course about the use of language besides courses about writing, speaking, listening, reading, etc. or language learners should focus on language skills only. The second one posed the issue of whether teachers should be equipped with the knowledge of pragmatics and introduce it in language skill classes.
The last one asked participants whether they thought pragmatics was vital in the process of learning a language.

The questionnaire for the fourth-year students was added, besides the ideas posed to first year students, with some details since they were doing the course of pragmatics when they provided their response to the questionnaire. One issue posed to them was to ask their perspective on the importance of the course of pragmatics.

The questionnaires were designed in 5-point Likert type scale structure, with 1 representing 'completely disagree' and 5 'completely agree' regarding the participants' opinion toward the statements in the questionnaire. The Cronbach's alpha reliability coefficient for the questionnaire for $1^{\text {st }}$ year and $4^{\text {th }}$ year students were .704 and .603 respectively, which meant the reliability of the instruments was acceptable.

\subsection{Data analysis}

The SPSS software, version 20, was used to analyze the data. T-test was applied to see the differences between the two groups, i.e. first year and fourth year students.

\section{Results}

\subsection{First year students' perspectives on pragmatic knowledge}

Table 1 presents the summary of the result collected from the questionnaire submitted by first year students. Seventeen (17) questions of the questionnaire were grouped into five (5) issues.

Table 1: Descriptive Statistics of data collected from questionnaire

\begin{tabular}{cccccc}
\hline \multicolumn{5}{c}{ Descriptive Statistics } \\
\hline & $\mathrm{N}$ & Minimum & Maximum & Mean & Std. Deviation \\
\hline Q1 & 102 & 1.00 & 5.00 & 4.0784 & .79212 \\
Q2 & 102 & 2.00 & 5.00 & 2.8431 & .84132 \\
Q3 & 102 & 2.00 & 5.00 & 3.9902 & .75117 \\
Q4 & 102 & 3.00 & 5.00 & 4.0490 & .72272 \\
Q5 & 102 & 2.00 & 5.00 & 4.1569 & .74122
\end{tabular}




\begin{tabular}{cccccc} 
Q6 & 102 & 3.00 & 5.00 & 4.1961 & .59767 \\
Q7 & 102 & 1.00 & 5.00 & 4.0392 & .81958 \\
Q8 & 102 & 2.00 & 5.00 & 3.9804 & .75754 \\
Q9 & 102 & 3.00 & 5.00 & 4.0588 & .64214 \\
Q10 & 102 & 2.00 & 5.00 & 4.0882 & .56469 \\
Q11 & 102 & 3.00 & 5.00 & 4.2059 & .66509 \\
Q12 & 102 & 1.00 & 5.00 & 2.9118 & .93452 \\
Q13 & 102 & 2.00 & 4.00 & 3.1373 & .59767 \\
Q14 & 102 & 1.00 & 5.00 & 3.9608 & .90018 \\
Q15 & 102 & 1.00 & 5.00 & 2.9412 & .96291 \\
Q16 & 102 & 1.00 & 5.00 & 4.0882 & .73259 \\
Q17 & 102 & 4.00 & 5.00 & 4.3725 & .48587 \\
\hline
\end{tabular}

Questions 1, 4, and 8 investigated the opinions of the participants about a course on pragmatics in their program. The results showed that students agreed with the idea of having a course about how to use language in their program (with a mean of 4.07, Std. deviation of .08). The majority of students surveyed were willing to take a course about how to use language (with a mean of 3.96, Std. deviation of .83). Also, they thought that it was essential to offer a course about how to use language to English-majored students (with a mean of 3.77, Std. deviation of 1.00).

Regarding the idea that only knowledge of language, namely vocabulary, grammar, etc., was needed for communication (Question 2 ), most students disagreed (with a mean of 2.5, and a Std. Deviation of .93). This means that most students thought it was necessary to include the knowledge of how to use language in their course to help them better communicate. On the other hand, most of them gave consent to the idea that the knowledge of how to use language should be included in the classrooms of language skills, and that only good knowledge did not guarantee success in communication (expressed in Question 3,7 , and 16 with means of $3.9,4.0$ and 4.0 respectively). We can infer that first-year students are aware of the role of pragmatics in their language competence.
Questions 5, 6, 9 and 10 posed the issues of exposing language learners to the knowledge of metalinguistics, such as culture, politeness, implicature, etc. The majority of participants (with means of 4.1, $4.1,4.0$, and 4.0 respectively) agreed that this kind of knowledge would help learners be more confident and successful in their communication. It is, therefore, obvious that freshmen did recognize the necessity of knowledge of pragmatics in their studies; they completely realized the importance of metalinguistic issues in their language learning.

Regarding the role of teachers in language classrooms, the issue was represented in three questions, each indicating a different aspect. Question 11 stated that teachers played a crucial role in helping learners understand issues related to culture or how to behave linguistically in language classrooms. The students indicated that they had a similar opinion, with a mean of 4.2 and a Std. Deviation of .66. Question 12 reversed the idea that it was the students' job to discover the issue of meta-linguistics. Dealing with this issue, students hesitated to express that they could discover the matter of language usage themselves, being illustrated by a mean of 2.9 and a Std. Deviation of .93. When asked to judge the strategy their teachers applied 
in classes regarding the issue of how to use language (Question 15), the majority of students hesitated to express a clear opinion. They seemed to be reluctant at indicating this matter, with a mean of 2.94 and Std. Deviation of .96. This indicated that students were not sure how their teachers should act, which is understandable as students and teachers have different jobs and focus.

When asked whether teachers presented knowledge of how to use language in language classes (Question 13), the students stated that they did not know that for sure, with a mean of 3.13 and Std. Deviation of .59. This could be inferred that either first year students were not able to recognize the knowledge of pragmatics presented in classes by their teachers or that teachers did not focus on the provision of pragmatic knowledge in their classes. As a result, most students preferred having the knowledge of pragmatics, e.g. politeness, implicatures (Question 14 and 17) included in their language classes, with a mean of 3.9 for Question 14 and 4.3 for Question 17 and a Std. Deviation of .9 for both.

\subsection{Fourth year students' perspectives on pragmatic knowledge}

Table 2 presents the summary of the result collected from the questionnaire submitted by fourth year students. Seventeen (17) questions of the questionnaire were grouped into five (5) issues.

Table 2: Descriptive Statistics of data collected from questionnaire

\begin{tabular}{c|ccccc}
\hline \multicolumn{7}{c}{ Descriptive Statistics } \\
\hline & $\mathrm{N}$ & Minimum & Maximum & Mean & Std. Deviation \\
\hline Q1 & 81 & 3.00 & 5.00 & 4.1481 & .57252 \\
Q2 & 81 & 2.00 & 3.00 & 2.3086 & .46481 \\
\hline Q3 & 81 & 3.00 & 5.00 & 3.9630 & .66039 \\
\hline Q4 & 81 & 2.00 & 4.00 & 2.9630 & .62138 \\
\hline Q5 & 81 & 3.00 & 5.00 & 4.0864 & .47952 \\
\hline Q6 & 81 & 3.00 & 5.00 & 4.3457 & .63562 \\
\hline Q7 & 81 & 2.00 & 5.00 & 4.1111 & .72457 \\
\hline Q8 & 81 & 3.00 & 5.00 & 4.1111 & .52440 \\
\hline Q9 & 81 & 3.00 & 5.00 & 4.1235 & .59964 \\
\hline Q10 & 81 & 3.00 & 5.00 & 4.1728 & .64788 \\
\hline Q11 & 81 & 2.00 & 5.00 & 4.3827 & .64358 \\
\hline Q12 & 81 & 2.00 & 4.00 & 2.8148 & .59395 \\
Q13 & 81 & 3.00 & 5.00 & 3.9877 & .53605 \\
\hline Q14 & 81 & 2.00 & 5.00 & 4.0864 & .82458 \\
Q15 & 81 & 3.00 & 5.00 & 4.1111 & .41833 \\
\hline Q16 & 81 & 3.00 & 5.00 & 4.2716 & .57036 \\
\hline Q17 & 81 & 3.00 & 5.00 & 4.4691 & .52646 \\
\hline
\end{tabular}

It should be noted here that fourth year students participated in this research six weeks after their course of pragmatics had started; therefore, they had a clear view of what pragmatics was. When asked about the role of the course of pragmatics (Question 1), most of them agreed that it played a vital role in language learning in general and in English courses in particular, with a mean of 4.1 and a Std. Deviation of .57. They supported the idea of offering a course about how to use language to English-majored students (Question 8), 
with a mean of 4.1 and a Std. Deviation of .52. However, participants hesitated when asked if they would like to take one more course about pragmatics (Question 4), with a mean of 2.9 and a Std. Deviation of .62. This could be explained that students felt that the amount of knowledge about pragmatics offered in this course was sufficient for them to be confident in real life communication.

Regarding the idea of only good knowledge of language being needed for success in communication (Question 2), the majority of students refuted this idea, with a mean of 2.3 and a Std. Deviation of .46. Students also consented that good knowledge about language did not guarantee success in communication (Question 7, with a mean of 4.1 and a Std. Deviation of .72). Most of them agreed that the knowledge of how to use language could help students better study the language skills (Question 3, with a mean of 3.9 and a Std. Deviation of .66), and that pragmatics should be included in language skills (Question 16, with a mean of 4.2 and a Std. Deviation of .57).

Questions 5, 6,9 and 10 expressed the role of pragmatics, including culture, politeness, etc., in communication. The majority of students consented that pragmatics was necessary in language classrooms and could help them be more confident in their communication (with means of 4.0, 4.3, 4.1, and 4.1 respectively).

Regarding the role of teachers in language teaching and learning (Question 11), students confirmed that teachers played vital roles in helping students understand knowledge of pragmatics, with a mean of 4.3 , and a Std. Deviation of .64. This goes accordingly with the fact that the majority of students disagreed with the idea that learners could achieve the knowledge of pragmatics (Question 12), with a mean of 2.8 and a Std. Deviation of .59. When asked about the issue of presenting the knowledge of how to use language in language classrooms, students reported that their teachers had not focused on the matter of pragmatics (Question 15, with a mean of 4.1 and a Std. Deviation of .41).

Regarding the roles of teachers in language classrooms, students stated that they did not have chances to gain the knowledge of pragmatics presented officially by their teachers (Question 13), with a mean of 3.9 and a Std. Deviation of .53. Therefore, they preferred the teachers to include pragmatic knowledge in language courses (Question 14), with a mean of 4.0 and a Std. Deviation of .82. Also, students would like their teachers to use proper methods in introducing the knowledge of how to use language in language classrooms (Question 17), with a mean of 4.4 and a Std. Deviation of .52.

\subsection{The two groups of students'perspectives on pragmatic knowledge}

In order to see the differences between the two groups, i.e. first- and fourth-year students, in their viewpoints, the Independent Samples T-Test was carried out. The output is attached in Appendix 2.

The result showed that the two groups had similar opinions in the majority of issues discussed, i.e. 13 out of 17 questions posed. This means that the $\mathrm{T}$ Test did not show any statistically significant difference between the two groups in answers of 13 questions. Those questions are $1,3,5,6,7,8,10,11$, 12, 14, 16, and 17. (See Appendix 1 for more information).

The output indicated that there were 4 issues that the two groups showed statistically significant differences $(p=.00)$. First, first year students could not make up their mind at 
the issue of judging whether good knowledge of language was enough for communication (Question 2), with a mean of 2.8, and a Std. Deviation of .08, while fourth year students, after studying English as a major for several years, strongly believed that knowledge of language was not enough for communication. They completely disagreed with the idea, with a mean of 2.3 and a Std. Deviation of .08.

Second, when asked if they were willing to take a course on pragmatics (Question 4), first year students were willing to make up their mind to say yes, with a mean of 4.0. This is different from fourth year students $(p=.00)$ who hesitated with the idea of taking another course in pragmatics, with a mean of 2.9. This could be explained that first year students were eager to take on new issues. Fourth year, answering the questionnaire while taking the course, might think one course was good enough and did not wish to take one more.

Third, regarding the issue of teachers presenting the knowledge of how to use language officially in classes of language, e.g. reading, writing, listening (Question 13), students from the two groups showed statistically significant difference $(p=.00)$ in their perspectives. While first year students were not sure whether their teacher introduced the knowledge of pragmatics in their language classes, with a mean of 3.1 , fourth year students were certain that their teachers did not do this in their language classes, with a mean of 3.9.

Fourth, when asked whether their teachers have included the knowledge of pragmatics in language classes or not (Question 15), first year students were not certain if that happened, with a mean of 2.9 and a Std. Deviation of .09. This is probably because first year students did not have a clear idea of what pragmatics was and they did not focus on this issue. This is statistically significant different $(p=.00)$ from fourth year students when they agreed that the knowledge of pragmatics was not paid much attention to in language courses at their school, with a mean of 4.1 and a Std. Deviation of .04. It is clear that fourth year students, after having had some time working with pragmatics, knew what it was about language use and they were able to realize those issues about pragmatics in language courses.

\subsection{Discussion}

The two groups showed similar perspectives on the role of pragmatics in language classes, which indicates that English-majored students are aware of the importance of the knowledge of how to use language in language classrooms. This in turn helps them succeed in their studies and eventually in their real-life communication. It is obvious that English-majored students realize the importance of pragmatics in their communication.

To a certain extent, language students participating in the study, especially fourth year students, have both practical and theoretical realization about pragmatic knowledge, which is quite different from Ekin and Damar (2013) who state that the students' "awareness was mostly on theoretical pragmatic knowledge". The evidence from this study is quite contradictory to Celis' (2017) result which states that "students with the most basic levels of English in linguistic terms display a higher pragmatic competence than those with more advanced levels".

Li et al. (2015) found out that Chinese EFL learners' socio-pragmatic competence is still underdeveloped due to students' ignorance of the different degrees of imposition present in different social contexts. This study validates their findings, regarding first year students who 
have not taken a course of pragmatics. Also, as stated previously, Nguyen, Pham, and Pham (2012) confirm that students with explicit metapragmatic explanation, and correction of pragmatic and grammatical errors outperform the group with implicit strategy. This study supports their strategy since it is apparent that language learners would like to be instructed with explicit explanation about how to use language, which would aid them in their communication.

Regarding the first difference between the two groups, first year students hesitated to decide whether good knowledge of language, i.e. vocabulary, grammar, etc., may or may not lead to success in communication, while fourth year students disagreed with the idea that only knowledge of language may lead to success. This could be attributed to the fact that fourth year students have experienced real-life English for a while in their real-life activities; therefore, they understood the role of pragmatics in communication. In an era when cross country communication is booming, the need of being equipped with appropriate usage of language is vital; therefore, language book writers and teachers should take this issue into consideration so as to provide language learners with sufficient pragmatic knowledge in their language classes. Explicit knowledge of pragmatics should be clearly included in language tasks, which would assist learners to acquire the underlying meaning of utterances. This in turns would help learners succeed in communication.

When asked if they were willing to take a course in pragmatics, first year students were unsure if it was a good choice while fourth year students, who had been taking the course of pragmatics for a while, stated that they did not think that was a good idea. This could be explained that first year students were not sure what pragmatics was and they could not make their mind whether it was necessary to take a course about pragmatics or it was enough to learn the knowledge of how to use language in language courses. Fourth year students had an idea what pragmatics was and how much was enough for them to be successful in their communication; therefore, they were sure that the course they were taking was enough for them in their usage of language when communicating in real life situations. As mentioned previously, explicit instructions about pragmatics should be provided to language learners as early as possible. If that is secured, language-majored students at higher education would be aware of the necessity of the knowledge of how to use language, thus promoting their willingness to take part in pragmatics courses or at least to be ready for the instruction of pragmatic knowledge at language classes.

The third difference between the two groups of students resided at the issue of whether the provision of pragmatic knowledge in language classes was carried out by language teachers. First year students had no idea if their teachers officially provided the knowledge of language usage, while fourth year students stated that they did not see the task of delivering pragmatic awareness in their language classes. It is quite obvious that it might be quite hard to recognize such subtle linguistic matters as pragmatic notions of presupposition, implicature, speech acts, etc. It is probably a fact that language teachers at secondary and high schools, and possibly in some classes at university may not save sufficient amount of time mentioning the pragmatic knowledge explicitly. This is possibly due to the amount of language knowledge they have to cover during limited time distributed in the program. Therefore, it is apparent that language teachers as well 
as language program designers should take this issue into consideration to make sure the knowledge of pragmatics be introduced in language classes.

Regarding the issue of language teachers' paying attention to the provision of pragmatic knowledge in language classes, first year students were reluctant to confirm while fourth year students completely agreed that their teachers did not focus on that. After having studied the course of pragmatics for a while, fourth year students were well aware of the knowledge of language use, which helped them recognize the availability of pragmatic issues presented in language classrooms. This indicates that the issue of presenting pragmatic knowledge in language classrooms in general is not obvious. Only English-majored students who take the course of pragmatics know about this issue. It is obviously necessary that the knowledge of language usage be introduced in language materials and then language classes, which would both equip language students with the conscious awareness of pragmatics, and ultimately help them be familiar with the usage of language in appropriate context, thus promoting success in communication.

\section{Conclusion}

The paper has made an attempt to discover the attitudes of first- and fourth-year students towards the role of pragmatics and related issues. Most students agreed that the knowledge of how to use language plays a vital role in language classrooms. The study revealed that first year students were not well aware of the issue relating to pragmatics, which indicates that the notions of language usage were not officially discussed in language classrooms.

Therefore, it is obvious that in language classes, the knowledge of pragmatics should be included in the learning and teaching activities to make sure that language learners are able to realize how to communicate appropriately, which plays a crucial part in the success of communication, the ultimate goal of language learning and teaching.

\section{References}

Bachman, L. (1990). Fundamental Considerations in Language Testing. Oxford: Oxford University Press.

Bardovi-Harlig, K., \& Dörnyei, Z. (1997). Pragmatic awareness and instructed L2 learning: An empirical investigation. Paper presented at the AAAL 1997 Conference. Orlando.

Bardovi-Harlig, K., Hartford, B. A. S., Mahan-Taylor, R., Morgan, M. J., \& Reynolds, D. W. (1991). Developing pragmatic awareness: Closing the conversation. ELT Journal, 45(1), 4-15.

Barron, A. (2003). Acquisition in interlanguage pragmatics: Learning how to do things with words in a study abroad context. Amsterdam: John Benjamins.

Byram, M., Gribkova, B., \& Starkey, H. (2002). Developing the Intercultural Dimension in Language Teaching: A practical introduction for teachers. Strasbourg: Council of Europe.

Celis, A. M. (2017). The Role of Pragmatics in English Teaching: A Study of Pragmatic Competence of Students from Spanish Institutions. Master thesis, Universidad Complutense de Madrid.

Chomsky, N. (1965). Aspects of the theory of syntax. Cambridge: Massachusetts Institute of Technology Press.

Ekin, M. T. Y., \& Damar, E. A. (2013). Pragmatic Awareness of EFL Teacher Trainees and Their Reflections on Pragmatic Practices. International Association of Research in Foreign Language Education and Applied Linguistics, 2(4), 176-190.

Eslami-Rasekh, Z. (2005). Raising the pragmatic awareness of language learners. ELT Journal, 59(3), 199-208. https://doi.org/10.1093/elt/cci039

Grossi, V. (2009). Teaching pragmatic competence: Compliments and compliment responses in the ESL classroom. Prospect, 24(2), 53-62.

Ifantidou, E. (2013). Pragmatic competence and explicit instruction. Journal of Pragmatics, 59, 93-116.

Kasper, G. (1997). The role of pragmatics in language teacher education. In K. Bardovi-Harlig \& B. Hartford (Eds.), Beyond Methods: Components of Second Language Teacher Education (pp. 113-136). New York: McGraw-Hill.

Le, T. T. H. (2006). Teaching communication strategies to Vietnamese learners of English. Doctoral thesis, Columbia University.

Li, R., Suleiman, R. R. R., \& Sazalie, A. (2015). An Investigation into Chinese EFL Learners' Pragmatic Competence. Gema Online Journal of Language 
Studies, 15(2), 101-118.

Nguyen, T. T. M., Pham, T. H., \& Pham, M. T. (2012). The relative effects of explicit and implicit formfocused instruction on the development of L2 pragmatic competence. Journal of Pragmatics, 44(4), 416-434.

Rezvani, E., Eslami-Rasekh, A., \& Dastjerdi, H. V. (2014). Investigating the effects of explicit and implicit instruction on Iranian EFL learners' pragmatic development: Speech acts of requests and suggestions in focus. International Journal of Research Studies in Language Teaching, 3(7), 3-14. https://doi.org/10.5861/ijirsll.2014.799

Schauer, G. A. (2006). Pragmatic Awareness in ESL and EFL Contexts: Contrast and Development. Language Learning, 56(2), 269-318.

Schmidt, R. W. (1995). Consciousness and Foreign Language Learning: A Tutorial on the Role of
Attention and Awareness in Learning. In R. W. Schmidt (Ed.), Attention and Awareness in Foreign Language Learning (pp. 1-63). Honolulu, HI: University of Hawaii Press.

Schmidt, R. W. (2010). Attention, Awareness, and Individual Differences in Language Learning. In W. M. Chan, S. Chi, K. N. Cin, J. Istanto, M. Nagami, J.W. Sew, T. Suthiwan \& I. Walker (Eds.), Proceedings of CLaSIC 2010 (pp. 721-737). Singapore: National University of Singapore, Centre for Language Studies.

Taguchi, N. (2009). Pragmatic competence in Japanese as a second language: An introduction. In N. Taguchi (Ed.), Pragmatic competence (pp. 1-18). Berlin: Mouton de Gruyter.

Vásquez, C., \& Sharpless, D. (2009). The role of pragmatics in the master's TESOL curriculum: Findings from a nationwide survey. TESOL Quarterly, 43(1), 5-28.

\title{
THÁI ĐỘ CỦA SINH VIÊN CHUYÊN NGŨ̉ TIẾNG ANH ĐỐI VỚI NHẬN THỨC VỀ NGỬ DỤNG HỌC
}

\author{
Nguyễn Tất Thắng \\ Trưòng Đại học Đà Lạt \\ Số 1 Phù Đổng Thiên Vương, Đà Lạt, Lâm Đồng, Việt Nam
}

Tóm tắt: Khả năng tốt về tiếng, như từ vựng, ngữ pháp, không nhất thiết đảm bảo cho sự thành công trong giao tiếp. Người học tiếng cần được trang bị về kiến thức ngôn ngữ cũng như kiến thức về cách thức sử dụng ngôn ngữ đó. Bài báo trình bày kết quả nghiên cứu về thái độ của sinh viên chuyên ngữ tiếng Anh tại một trường đại học ở Việt Nam đối với kiến thức ngữ dụng học. Dữ liệu được thu thập thông qua bảng khảo sát. Phần mềm SPSS phiên bản 20 được sử dụng để phân tích dữ liệu. Kết quả cho thấy phần lớn sinh viên chuyên ngữ nhận thức được vai trò của ngữ dụng học trong các học phần ngôn ngữ. Sinh viên năm 1 và sinh viên năm cuối khác nhau ở 3 vấn đề: 1) quan điểm về kiến thức ngôn ngữ đủ hay chưa đủ cho mục đích giao tiếp; 2) sự sẵn sàng để học về ngữ dụng học; và 3) vai trò của giảng viên trong việc truyền tải kiến thức ngữ dụng trong các lớp học ngôn ngữ. Từ đó cho thấy việc giới thiệu kiến thức về cách sử dụng ngôn ngữ đóng vai trò quan trọng trong biên soạn tài liệu và trong các hoạt động giảng dạy ngôn ngữ.

Từ khóa: ngữ dụng, giao tiếp, quan điểm, cách sử dụng ngôn ngữ 


\section{Appendices}

\section{Appendix 1: Questionnaire for first year English-majored students}

\section{Dear students,}

We are conducting a study with English language learners about the use of language in teaching and learning language at Dalat University, i.e. English. We would like to have your opinion towards the following statements. We confirm that all information will be kept confidential and be used only for the purpose of the study.

Please circle 1 to 5 according to the following coding:
1. Completely disagree
2. Disagree
3. No idea
4. Agree 5. Completely agree

\begin{tabular}{|c|c|c|c|c|c|c|}
\hline No. & Statements & $\begin{array}{c}\text { Completely } \\
\text { disagree }\end{array}$ & Disagree & No ideas & Agree & $\begin{array}{c}\text { Completely } \\
\text { agree }\end{array}$ \\
\hline 1 & $\begin{array}{c}\text { Apart from language } \\
\text { courses like reading, } \\
\text { writing, speaking, } \\
\text { listening, grammar, etc., } \\
\text { there should be courses } \\
\text { about how to use language } \\
\text { (related to culture, } \\
\text { politeness, etc.) }\end{array}$ & 1 & 2 & 3 & 4 & 5 \\
\hline 2 & $\begin{array}{c}\text { We just need good } \\
\text { knowledge of language } \\
\text { (i.e. vocabulary, grammar, } \\
\text { intonation, etc.) to help us } \\
\text { succeed in communication. }\end{array}$ & 1 & 2 & 3 & 4 & 5 \\
\hline 3 & $\begin{array}{c}\text { If we have good } \\
\text { knowledge of how to use a } \\
\text { language, we will be able } \\
\text { to better study language } \\
\text { courses, e.g. Reading, } \\
\text { Listening, Speaking, etc. }\end{array}$ & 1 & 2 & 3 & 4 & 5 \\
\hline 4 & $\begin{array}{c}\text { I am willing to take a } \\
\text { course about how to use } \\
\text { language. }\end{array}$ & 1 & 2 & 3 & 5 & 5 \\
\hline 5 & $\begin{array}{c}\text { Studying how to use } \\
\text { language will help } \\
\text { language learners be more } \\
\text { confident and successful in } \\
\text { communication. }\end{array}$ & $\begin{array}{c}\text { If we are equipped with the } \\
\text { culture of English speaking } \\
\text { countries, we will be able } \\
\text { to study English better. }\end{array}$ & 1 & 2 & 3 & 5 \\
\hline
\end{tabular}




\begin{tabular}{|c|c|c|c|c|c|c|}
\hline 7 & $\begin{array}{l}\text { Good knowledge about } \\
\text { language (e.g. vocabulary, } \\
\text { grammar, etc.) does not } \\
\text { guarantee success in } \\
\text { communication. }\end{array}$ & 1 & 2 & 3 & 4 & 5 \\
\hline 8 & $\begin{array}{l}\text { It is essential to offer a } \\
\text { course about how to use } \\
\text { language for English } \\
\text { majored students. }\end{array}$ & 1 & 2 & 3 & 4 & 5 \\
\hline 9 & $\begin{array}{l}\text { The culture of English } \\
\text { speaking countries should } \\
\text { be included in all courses } \\
\text { so that learners would } \\
\text { know more about how to } \\
\text { use language and therefore } \\
\text { use it more appropriately. }\end{array}$ & 1 & 2 & 3 & 4 & 5 \\
\hline 10 & $\begin{array}{l}\text { Knowledge of how to use } \\
\text { language, e.g. implicatures, } \\
\text { politeness, etc. will help } \\
\text { learners understand more } \\
\text { about the language and } \\
\text { be more confident in their } \\
\text { communication. }\end{array}$ & 1 & 2 & 3 & 4 & 5 \\
\hline 11 & $\begin{array}{c}\text { Teachers play a crucial } \\
\text { role in helping learners } \\
\text { understand issues related } \\
\text { to culture or how to behave } \\
\text { linguistically in language } \\
\text { classrooms. }\end{array}$ & 1 & 2 & 3 & 4 & 5 \\
\hline 12 & $\begin{array}{l}\text { It is teachers' main role to } \\
\text { help learners get language } \\
\text { knowledge of vocabulary, } \\
\text { grammar. } \\
\text { Other issues like politeness, } \\
\text { implicatures, etc. will be } \\
\text { the learners' job. }\end{array}$ & 1 & 2 & 3 & 4 & 5 \\
\hline 13 & $\begin{array}{l}\text { When studying courses like } \\
\text { reading, writing, listening, } \\
\text { etc., I do not have a } \\
\text { chance to know how to use } \\
\text { language presented by my } \\
\text { teacher officially. }\end{array}$ & 1 & 2 & 3 & 4 & 5 \\
\hline 14 & $\begin{array}{l}\text { I think if teachers include } \\
\text { the knowledge of how } \\
\text { to use language in their } \\
\text { language courses, learners } \\
\text { will study the language } \\
\text { more successfully. }\end{array}$ & 1 & 2 & 3 & 4 & 5 \\
\hline
\end{tabular}




\begin{tabular}{|c|c|c|c|c|c|c|}
\hline 15 & $\begin{array}{l}\text { I think my English teachers } \\
\text { have not focused on how } \\
\text { to use the language. They } \\
\text { have just paid attention to } \\
\text { language skills only, e.g. } \\
\text { vocabulary, grammar, etc. }\end{array}$ & 1 & 2 & 3 & 4 & 5 \\
\hline 16 & $\begin{array}{l}\text { The knowledge of how } \\
\text { to use language should } \\
\text { be included in language } \\
\text { classes of reading, } \\
\text { listening, writing, } \\
\text { grammar, etc. }\end{array}$ & 1 & 2 & 3 & 4 & 5 \\
\hline 17 & $\begin{array}{l}\text { Paralinguistic issues, i.e. } \\
\text { politeness, implicatures, } \\
\text { etc., are hard to acquire; } \\
\text { therefore, teachers should } \\
\text { employ proper methods to } \\
\text { help students understand } \\
\text { them. }\end{array}$ & 1 & 2 & 3 & 4 & 5 \\
\hline
\end{tabular}

\section{THANK YOU FOR YOUR COOPERATION.}

\section{Questionnaire for fourth year English-majored students}

Dear students,

We are conducting a study with English language learners about the use of language in teaching and learning language at Dalat University, i.e. English. We would like to have your opinion towards the following statements. We confirm that all information will be kept confidential and be used only for the purpose of the study.

Please circle 1 to 5 according to following coding:
1. Completely disagree
2. Disagree
3. No idea
4. Agree 5. Completely agree

\begin{tabular}{|c|c|c|c|c|c|c|}
\hline No. & Statements & $\begin{array}{c}\text { Completely } \\
\text { disagree }\end{array}$ & Disagree & No ideas & Agree & $\begin{array}{c}\text { Completely } \\
\text { agree }\end{array}$ \\
\hline 1 & $\begin{array}{c}\text { This pragmatics course is } \\
\text { necessary for learners of language } \\
\text { in general and of English in } \\
\text { particular. }\end{array}$ & 1 & 2 & 3 & 4 & 5 \\
\hline 2 & 1 & 2 & 3 & 4 & 5 \\
\hline 3 & $\begin{array}{c}\text { We just need good knowledge } \\
\text { of language (i.e. vocabulary, } \\
\text { grammar, intonation, etc.) to help } \\
\text { us succeed in communication. }\end{array}$ & $\begin{array}{c}\text { If we have good knowledge of how } \\
\text { to use a language, we will be able } \\
\text { to better study language courses, } \\
\text { e.g. Reading, Listening, Speaking, } \\
\text { etc. }\end{array}$ & 1 & 2 & 3 & 4 \\
\hline
\end{tabular}




\begin{tabular}{|c|c|c|c|c|c|c|}
\hline 4 & $\begin{array}{l}\text { I am willing to take another } \\
\text { course on pragmatics to learn } \\
\text { more about pragmatics. }\end{array}$ & 1 & 2 & 3 & 4 & 5 \\
\hline 5 & $\begin{array}{c}\text { Studying how to use language } \\
\text { will help language learners be } \\
\text { more confident and successful in } \\
\text { communication. }\end{array}$ & 1 & 2 & 3 & 4 & 5 \\
\hline 6 & $\begin{array}{l}\text { If we are equipped with the } \\
\text { culture of English speaking } \\
\text { countries, we will be able to } \\
\text { study English better. }\end{array}$ & 1 & 2 & 3 & 4 & 5 \\
\hline 7 & $\begin{array}{c}\text { Good knowledge about language } \\
\text { (e.g. vocabulary, grammar, etc.) } \\
\text { does not guarantee success in } \\
\text { communication. }\end{array}$ & 1 & 2 & 3 & 4 & 5 \\
\hline 8 & $\begin{array}{l}\text { It is essential to offer a course } \\
\text { about how to use language for } \\
\text { English majored students. }\end{array}$ & 1 & 2 & 3 & 4 & 5 \\
\hline 9 & $\begin{array}{l}\text { The culture of English speaking } \\
\text { countries should be included } \\
\text { in all courses so that learners } \\
\text { would know more about how to } \\
\text { use language and therefore use it } \\
\text { more appropriately. }\end{array}$ & 1 & 2 & 3 & 4 & 5 \\
\hline 10 & $\begin{array}{l}\text { Knowledge of how to use } \\
\text { language, e.g. implicatures, } \\
\text { politeness, etc. will help learners } \\
\text { understand more about the } \\
\text { language and be more confident } \\
\text { in their communication. }\end{array}$ & 1 & 2 & 3 & 4 & 5 \\
\hline 11 & $\begin{array}{c}\text { Teachers play a crucial role in } \\
\text { helping learners understand } \\
\text { issues related to culture or how to } \\
\text { behave linguistically in language } \\
\text { classrooms. }\end{array}$ & 1 & 2 & 3 & 4 & 5 \\
\hline 12 & $\begin{array}{c}\text { It is teachers' main role to help } \\
\text { learners get language knowledge of } \\
\text { vocabulary, grammar. } \\
\text { Other issues like politeness, } \\
\text { implicatures, etc. will be the } \\
\text { learners' job. }\end{array}$ & 1 & 2 & 3 & 4 & 5 \\
\hline 13 & $\begin{array}{c}\text { When studying courses like } \\
\text { reading, writing, listening, etc., } \\
\text { I do not have a chance to know } \\
\text { how to use language presented by } \\
\text { my teacher officially. }\end{array}$ & 1 & 2 & 3 & 4 & 5 \\
\hline
\end{tabular}




\begin{tabular}{|c|c|c|c|c|c|c|}
\hline 14 & $\begin{array}{l}\text { I think if teachers include } \\
\text { the knowledge of how to use } \\
\text { language in their language } \\
\text { courses, learners will study the } \\
\text { language more successfully. }\end{array}$ & 1 & 2 & 3 & 4 & 5 \\
\hline 15 & $\begin{array}{l}\text { I think my English teachers have } \\
\text { not focused on how to use the } \\
\text { language. They have just paid } \\
\text { attention to language skills only, } \\
\text { e.g. vocabulary, grammar, etc. }\end{array}$ & 1 & 2 & 3 & 4 & 5 \\
\hline 16 & $\begin{array}{l}\text { The knowledge of how to use } \\
\text { language should be included } \\
\text { in language classes of reading, } \\
\text { listening, writing, grammar, etc. }\end{array}$ & 1 & 2 & 3 & 4 & 5 \\
\hline 17 & $\begin{array}{l}\text { Paralinguistic issues, i.e. } \\
\text { politeness, implicatures, etc., } \\
\text { are hard to acquire; therefore, } \\
\text { teachers should employ proper } \\
\text { methods to help students } \\
\text { understand them. }\end{array}$ & 1 & 2 & 3 & 4 & 5 \\
\hline
\end{tabular}

THANK YOU FOR YOUR COOPERATION.

Appendix 2. Output of Independent Samples T Test

\begin{tabular}{|c|c|c|c|c|c|}
\hline \multicolumn{6}{|c|}{ Group Statistics } \\
\hline & Year & $\mathrm{N}$ & Mean & Std. Deviation & Std. Error Mean \\
\hline \multirow{2}{*}{ Q1 } & Year 1 & 102 & 4.0784 & .79212 & .07843 \\
\hline & Year 4 & 81 & 4.1481 & .57252 & .06361 \\
\hline \multirow{2}{*}{ Q2 } & Year 1 & 102 & 2.8431 & .84132 & .08330 \\
\hline & Year 4 & 81 & 2.3086 & .46481 & .05165 \\
\hline \multirow{2}{*}{ Q3 } & Year 1 & 102 & 3.9902 & .75117 & .07438 \\
\hline & Year 4 & 81 & 3.9630 & .66039 & .07338 \\
\hline \multirow{2}{*}{ Q4 } & Year 1 & 102 & 4.0490 & .72272 & .07156 \\
\hline & Year 4 & 81 & 2.9630 & .62138 & .06904 \\
\hline \multirow{2}{*}{ Q5 } & Year 1 & 102 & 4.1569 & .74122 & .07339 \\
\hline & Year 4 & 81 & 4.0864 & .47952 & .05328 \\
\hline \multirow{2}{*}{ Q6 } & Year 1 & 102 & 4.1961 & .59767 & .05918 \\
\hline & Year 4 & 81 & 4.3457 & .63562 & .07062 \\
\hline \multirow{2}{*}{ Q7 } & Year 1 & 102 & 4.0392 & .81958 & .08115 \\
\hline & Year 4 & 81 & 4.1111 & .72457 & .08051 \\
\hline \multirow{2}{*}{ Q8 } & Year 1 & 102 & 3.9804 & .75754 & .07501 \\
\hline & Year 4 & 81 & 4.1111 & .52440 & .05827 \\
\hline \multirow{2}{*}{ Q9 } & Year 1 & 102 & 4.0588 & .64214 & .06358 \\
\hline & Year 4 & 81 & 4.1235 & .59964 & .06663 \\
\hline \multirow{2}{*}{ Q10 } & Year 1 & 102 & 4.0882 & .56469 & .05591 \\
\hline & Year 4 & 81 & 4.1728 & .64788 & .07199 \\
\hline
\end{tabular}




\begin{tabular}{|c|c|c|c|c|c|}
\hline \multirow{2}{*}{ Q11 } & Year 1 & 102 & 4.2059 & .66509 & .06585 \\
\cline { 2 - 6 } & Year 4 & 81 & 4.3827 & .64358 & .07151 \\
\hline \multirow{2}{*}{ Q12 } & Year 1 & 102 & 2.9118 & .93452 & .09253 \\
\cline { 2 - 6 } & Year 4 & 81 & 2.8148 & .59395 & .06599 \\
\hline \multirow{2}{*}{ Q13 } & Year 1 & 102 & 3.1373 & .59767 & .05918 \\
\cline { 2 - 6 } & Year 4 & 81 & 3.9877 & .53605 & .05956 \\
\hline \multirow{2}{*}{ Q14 } & Year 1 & 102 & 3.9608 & .90018 & .08913 \\
\cline { 2 - 6 } & Year 4 & 81 & 4.0864 & .82458 & .09162 \\
\hline \multirow{2}{*}{ Q15 } & Year 1 & 102 & 2.9412 & .96291 & .09534 \\
\cline { 2 - 6 } & Year 4 & 81 & 4.1111 & .41833 & .04648 \\
\hline \multirow{2}{*}{ Q16 } & Year 1 & 102 & 4.0882 & .73259 & .07254 \\
\cline { 2 - 6 } & Year 4 & 81 & 4.2716 & .57036 & .06337 \\
\hline \multirow{2}{*}{ Q17 } & Year 1 & 102 & 4.3725 & .48587 & .04811 \\
\cline { 2 - 6 } & Year 4 & 81 & 4.4691 & .52646 & .05850 \\
\hline
\end{tabular}

\begin{tabular}{|c|c|c|c|c|c|c|c|c|c|c|}
\hline \multicolumn{11}{|c|}{ Independent Samples Test } \\
\hline & & $\begin{array}{l}\text { Levene } \\
\text { for Eq } \\
\text { of Var }\end{array}$ & $\begin{array}{l}\text { S Test } \\
\text { ality } \\
\text { inces }\end{array}$ & \multicolumn{7}{|c|}{ t-test for Equality of Means } \\
\hline & & \multirow[t]{2}{*}{$\mathrm{F}$} & \multirow[t]{2}{*}{ Sig. } & \multirow[t]{2}{*}{$\mathrm{t}$} & \multirow[t]{2}{*}{$\mathrm{df}$} & \multirow[t]{2}{*}{$\begin{array}{c}\text { Sig. } \\
\text { (2-tailed) }\end{array}$} & \multirow[t]{2}{*}{$\begin{array}{c}\text { Mean } \\
\text { Difference }\end{array}$} & \multirow[t]{2}{*}{$\begin{array}{l}\text { Std. Error } \\
\text { Difference }\end{array}$} & \multicolumn{2}{|c|}{$\begin{array}{l}95 \% \text { Confidence } \\
\text { Interval of the } \\
\text { Difference }\end{array}$} \\
\hline & & & & & & & & & Lower & Upper \\
\hline \multirow[b]{2}{*}{ Q1 } & $\begin{array}{c}\text { Equal } \\
\text { variances } \\
\text { assumed }\end{array}$ & 3.677 & .057 & -.666 & 181 & .506 & -.06972 & .10471 & -.27632 & .13689 \\
\hline & $\begin{array}{c}\text { Equal } \\
\text { variances } \\
\text { not } \\
\text { assumed } \\
\end{array}$ & & & -.690 & 179.514 & .491 & -.06972 & .10099 & -.26899 & .12956 \\
\hline \multirow[b]{2}{*}{ Q2 } & $\begin{array}{c}\text { Equal } \\
\text { variances } \\
\text { assumed }\end{array}$ & 23.550 & .000 & 5.128 & 181 & .000 & .53450 & .10423 & .32884 & .74015 \\
\hline & $\begin{array}{c}\text { Equal } \\
\text { variances } \\
\text { not } \\
\text { assumed }\end{array}$ & & & 5.453 & 163.135 & .000 & .53450 & .09801 & .34096 & .72803 \\
\hline \multirow[b]{2}{*}{ Q3 } & $\begin{array}{c}\text { Equal } \\
\text { variances } \\
\text { assumed }\end{array}$ & .035 & .851 & .257 & 181 & .798 & .02723 & .10604 & -.18199 & .23646 \\
\hline & $\begin{array}{c}\text { Equal } \\
\text { variances } \\
\text { not } \\
\text { assumed }\end{array}$ & & & .261 & 179.094 & .795 & .02723 & .10448 & -.17894 & .23340 \\
\hline \multirow[b]{2}{*}{ Q4 } & $\begin{array}{c}\text { Equal } \\
\text { variances } \\
\text { assumed }\end{array}$ & 3.754 & .054 & 10.735 & 181 & .000 & 1.08606 & .10117 & .88643 & 1.28568 \\
\hline & $\begin{array}{c}\text { Equal } \\
\text { variances } \\
\text { not } \\
\text { assumed }\end{array}$ & & & 10.922 & 179.827 & .000 & 1.08606 & .09944 & .88984 & 1.28227 \\
\hline
\end{tabular}




\begin{tabular}{|c|c|c|c|c|c|c|c|c|c|c|}
\hline \multirow[b]{2}{*}{ Q5 } & $\begin{array}{c}\text { Equal } \\
\text { variances } \\
\text { assumed }\end{array}$ & 17.024 & .000 & .741 & 181 & .460 & .07044 & .09509 & -.11718 & .25807 \\
\hline & $\begin{array}{c}\text { Equal } \\
\text { variances } \\
\text { not } \\
\text { assumed }\end{array}$ & & & .777 & 174.368 & .438 & .07044 & .09069 & -.10855 & .24944 \\
\hline \multirow[b]{2}{*}{ Q6 } & $\begin{array}{c}\text { Equal } \\
\text { variances } \\
\text { assumed }\end{array}$ & 3.556 & .061 & -1.635 & 181 & .104 & -.14960 & .09149 & -.33012 & .03092 \\
\hline & $\begin{array}{c}\text { Equal } \\
\text { variances } \\
\text { not } \\
\text { assumed }\end{array}$ & & & -1.624 & 166.690 & .106 & -.14960 & .09214 & -.33151 & .03231 \\
\hline \multirow[b]{2}{*}{ Q7 } & $\begin{array}{c}\text { Equal } \\
\text { variances } \\
\text { assumed }\end{array}$ & .064 & .800 & -.620 & 181 & .536 & -.07190 & .11594 & -.30066 & .15687 \\
\hline & $\begin{array}{c}\text { Equal } \\
\text { variances } \\
\text { not } \\
\text { assumed }\end{array}$ & & & -.629 & 178.882 & .530 & -.07190 & .11431 & -.29747 & .15368 \\
\hline \multirow[b]{2}{*}{ Q8 } & $\begin{array}{c}\text { Equal } \\
\text { variances } \\
\text { assumed } \\
\end{array}$ & 9.133 & .003 & -1.321 & 181 & .188 & -.13072 & .09892 & -.32590 & .06446 \\
\hline & $\begin{array}{c}\text { Equal } \\
\text { variances } \\
\text { not } \\
\text { assumed }\end{array}$ & & & -1.376 & 177.892 & .170 & -.13072 & .09498 & -.31815 & .05671 \\
\hline \multirow[b]{2}{*}{ Q9 } & $\begin{array}{c}\text { Equal } \\
\text { variances } \\
\text { assumed }\end{array}$ & .023 & .879 & -.696 & 181 & .487 & -.06463 & .09283 & -.24779 & .11853 \\
\hline & $\begin{array}{c}\text { Equal } \\
\text { variances } \\
\text { not } \\
\text { assumed }\end{array}$ & & & -.702 & 176.266 & .484 & -.06463 & .09210 & -.24639 & .11712 \\
\hline \multirow[b]{2}{*}{ Q10 } & $\begin{array}{c}\text { Equal } \\
\text { variances } \\
\text { assumed }\end{array}$ & 6.051 & .015 & -.943 & 181 & .347 & -.08460 & .08972 & -.26164 & .09244 \\
\hline & $\begin{array}{c}\text { Equal } \\
\text { variances } \\
\text { not } \\
\text { assumed } \\
\end{array}$ & & & -.928 & 159.623 & .355 & -.08460 & .09115 & -.26462 & .09541 \\
\hline \multirow[b]{2}{*}{ Q11 } & $\begin{array}{c}\text { Equal } \\
\text { variances } \\
\text { assumed }\end{array}$ & .135 & .714 & -1.812 & 181 & .072 & -.17683 & .09758 & -.36938 & .01571 \\
\hline & $\begin{array}{c}\text { Equal } \\
\text { variances } \\
\text { not } \\
\text { assumed } \\
\end{array}$ & & & -1.819 & 174.067 & .071 & -.17683 & .09721 & -.36870 & .01503 \\
\hline
\end{tabular}




\begin{tabular}{|c|c|c|c|c|c|c|c|c|c|c|}
\hline \multirow[b]{2}{*}{ Q12 } & $\begin{array}{c}\text { Equal } \\
\text { variances } \\
\text { assumed }\end{array}$ & 12.196 & .001 & .812 & 181 & .418 & .09695 & .11936 & -.13857 & .33247 \\
\hline & $\begin{array}{c}\text { Equal } \\
\text { variances } \\
\text { not } \\
\text { assumed }\end{array}$ & & & .853 & 173.280 & .395 & .09695 & .11365 & -.12738 & .32127 \\
\hline \multirow[b]{2}{*}{ Q13 } & $\begin{array}{c}\text { Equal } \\
\text { variances } \\
\text { assumed }\end{array}$ & 5.465 & .020 & -10.003 & 181 & .000 & -.85040 & .08502 & -1.01815 & -.68264 \\
\hline & $\begin{array}{c}\text { Equal } \\
\text { variances } \\
\text { not } \\
\text { assumed }\end{array}$ & & & -10.128 & 178.290 & .000 & -.85040 & .08396 & -1.01609 & -.68471 \\
\hline \multirow[b]{2}{*}{ Q14 } & $\begin{array}{c}\text { Equal } \\
\text { variances } \\
\text { assumed }\end{array}$ & .001 & .973 & -.973 & 181 & .332 & -.12564 & .12912 & -.38041 & .12914 \\
\hline & $\begin{array}{c}\text { Equal } \\
\text { variances } \\
\text { not } \\
\text { assumed }\end{array}$ & & & -.983 & 177.296 & .327 & -.12564 & .12782 & -.37789 & .12661 \\
\hline \multirow[b]{2}{*}{ Q15 } & $\begin{array}{c}\text { Equal } \\
\text { variances } \\
\text { assumed }\end{array}$ & 28.476 & .000 & -10.193 & 181 & .000 & -1.16993 & .11477 & -1.39640 & -.94347 \\
\hline & $\begin{array}{c}\text { Equal } \\
\text { variances } \\
\text { not } \\
\text { assumed } \\
\end{array}$ & & & -11.030 & 144.416 & .000 & -1.16993 & .10607 & -1.37958 & -.96029 \\
\hline \multirow[b]{2}{*}{ Q16 } & $\begin{array}{c}\text { Equal } \\
\text { variances } \\
\text { assumed }\end{array}$ & .002 & .966 & -1.851 & 181 & .066 & -.18337 & .09909 & -.37888 & .01214 \\
\hline & $\begin{array}{c}\text { Equal } \\
\text { variances } \\
\text { not } \\
\text { assumed } \\
\end{array}$ & & & -1.904 & 180.939 & .059 & -.18337 & .09632 & -.37343 & .00669 \\
\hline \multirow[b]{2}{*}{ Q17 } & $\begin{array}{c}\text { Equal } \\
\text { variances } \\
\text { assumed }\end{array}$ & 6.106 & .014 & -1.287 & 181 & .200 & -.09659 & .07504 & -.24465 & .05148 \\
\hline & $\begin{array}{c}\text { Equal } \\
\text { variances } \\
\text { not } \\
\text { assumed }\end{array}$ & & & -1.275 & 165.022 & .204 & -.09659 & .07574 & -.24613 & .05295 \\
\hline
\end{tabular}

